\title{
Effects of Inhaled Nitric Oxide on Oxidative Stress and Histopathological and Inflammatory Lung Injury in a Saline-Lavaged Rabbit Model of Acute Lung Injury
}

\author{
Jose R Fioretto MD PhD, Fabio J Campos MD, Carlos F Ronchi MD, Ana LA Ferreira MD PhD, \\ Cilmery S Kurokawa PhD, Mario F Carpi, Marcos A Moraes MD PhD, \\ Rossano C Bonatto MD PhD, Julio Defaveri MD PhD, and Kyung-Jin Yeum MD PhD
}

\begin{abstract}
BACKGROUND: Conventional mechanical ventilation (CMV) is fundamental in acute respiratory distress syndrome (ARDS) treatment. Inhaled nitric oxide (INO), an adjunctive therapy, has been used with ventilation in an attempt to improve oxygenation and reduce lung injury. OBJECTIVE: To analyze the early effects of low INO dose on oxygenation, oxidative stress, inflammatory, and histopathological lung injury in a rabbit model of acute lung injury (ALI). METHODS: This was a prospective, controlled, in vivo animal laboratory study. Forty rabbits were instrumented and ventilated at $\mathrm{F}_{\mathrm{IO}}, 1.0$. ALI was induced by tracheal infusion of warm saline $\left(30 \mathrm{~mL} / \mathrm{kg}, 38^{\circ} \mathrm{C}\right)$ and lung oxidative stress was assessed by total antioxidant performance (TAP) assay. Animals were assigned to groups: control group (no. $=10$, low tidal volume $\left[\mathrm{V}_{\mathrm{T}}\right]=6 \mathrm{~mL} / \mathrm{kg}, \mathrm{PEEP}=5 \mathrm{~cm} \mathrm{H}_{2} \mathrm{O}$ ), ALI without INO (no-INO group, no. $=10$, low $V_{T}=6 \mathrm{~mL} / \mathrm{kg}$, PEEP $=10 \mathrm{~cm} \mathrm{H}_{2} \mathrm{O}$ ), ALI plus INO (INO group, no. $=10$, low $V_{T}=6 \mathrm{~mL} / \mathrm{kg}$, PEEP $=10 \mathrm{~cm} \mathrm{H} \mathrm{H}_{2} \mathrm{O}$, INO $=5 \mathrm{ppm}$ ). Plateau pressure was limited to $30 \mathrm{~cm} \mathrm{H}_{2} \mathrm{O}$ in all groups. Ten non-instrumented animals (healthy group) were studied for TAP assay. Ventilatory and hemodynamic parameters were recorded every 30 min for 4 hours. RESULTS: After lung injury, the instrumented groups were worse than the control group for $\mathbf{P}_{\mathrm{aO}_{2}}$ (control group $438 \pm 87 \mathrm{~mm} \mathrm{Hg}$, no-INO group $80 \pm 13 \mathrm{~mm} \mathrm{Hg}$, INO group $81 \pm 24 \mathrm{~mm} \mathrm{Hg}, P<$ $.001)$. The INO group showed decreased lung inflammation by leukocyte count in lung lavage fluid (no-INO group $4.8 \pm 1.64$, control group $0.16 \pm 0.15$, INO group $0.96 \pm 0.35$ polymorphonuclear cells $\times 10^{6} / \mathrm{bronchoalveolar} \mathrm{lavage} \mathrm{fluid/lung,} P<.001$ ), decreased histopathological injury score (no-INO group 5 [range 1-16], INO group 2 [range 0-5], control group 0 [range 0-3], $P<.001$ ), and better lung protection against oxidative injury than the no-INO group (healthy group $68 \pm 8.7$, control group $66.4 \pm 6.8$, INO group $56.3 \pm 5.1$, no-INO group $45.9 \pm 3.4$ percent protection/g protein, $P<.001)$. CONCLUSIONS: INO attenuates oxidative stress and histopathological and inflammatory lung injury in a saline-lavaged rabbit ALI model. Key words: ARDS; mechanical ventilation; oxidative injury; acute lung injury; rabbits; inhaled nitric oxide. [Respir Care 2012;57(2): 273-281. (c) 2012 Daedalus Enterprises]
\end{abstract}

\footnotetext{
Dr Fioretto, Dr Ronchi, Dr Kurokawa, Mr Carpi, Dr Moraes, and Dr Bonatto are affiliated with Departamento de Pediatria Botucatu; Dr Ferreira is affiliated with the Internal Medicine Department; and Dr Defaveri is affiliated with the Pathology Department, Faculdade de Medicina de Botucatu, Sao Paulo State University, Sao Paulo, Brazil. Dr Campos is affiliated with the Marilia Medical School, Marilia, Sao Paulo, Brazil. Dr Ronchi and Dr Yeum are affiliated with the Jean Mayer USDA Human Nutrition Research Center on Aging, Tufts University, Boston Massachusetts.
}

\begin{abstract}
This research was partly supported by the Sao Paulo State Research Support Foundation (2007/03173-2). The authors have disclosed no conflicts of interest.

Correspondence: Jose R Fioretto MD PhD, Departamento de Pediatria Botucatu, Faculdade de Medicina de Botucatu, Sao Paulo State University, Sao Paulo 18.681-970 Brazil. E-mail: jrf@fmb.unesp.br.
\end{abstract}

DOI: $10.4187 /$ respcare.01289 


\section{Introduction}

Acute respiratory distress syndrome (ARDS), the most severe manifestation of acute lung injury (ALI), is still one of the biggest challenges in critical care medicine. ${ }^{1}$ Despite better understanding of ARDS pathophysiology, the mechanisms are still under investigation. Briefly, an inflammatory process disrupts the alveolar capillary barrier with interstitial and alveolar edema. In addition, reactive oxygen species and reactive nitrogen species can play an important role in pulmonary vascular endothelial inflammatory damage, which may be responsible for syndrome development and progression. ${ }^{2}$

Mechanical ventilation is one of the most important supportive treatments in ARDS, having a significant impact on mortality. ${ }^{3}$ Systemic inflammatory cytokine release also reduces when protective conventional mechanical ventilation (CMV) is used. ${ }^{4}$ In contrast, experimental studies have shown that nonprotective mechanical ventilation increases the inflammatory process and disrupts alveoli surface integrity due to overdistention and cyclic reopening/collapse..$^{5}$

The pathophysiological complexity and seriousness of some ARDS cases may require adjunct treatments such as inhaled nitric oxide (INO). ${ }^{6}$

In 2004, we compared pressure control ventilation with and without early INO administration in children with ARDS, where INO was introduced as early as 1.5 hours after diagnosis, leading to acute improvements in oxygenation indexes. Prolonged treatment was also associated with improved oxygenation, so that $\mathrm{F}_{\mathrm{IO}_{2}}$ and peak inspiratory pressure could be quickly and significantly reduced. We concluded that early INO treatment provides an acute and sustained improvement in oxygenation, and earlier reductions away from ventilator settings linked with a high risk of ventilator-induced lung injury and oxygen toxicity; this may help reduce mechanical ventilation aggressiveness and attenuate inflammatory lung injury. ${ }^{7}$

Nitric oxide inhalation is also not free of toxic effects, mainly from peroxynitrite $\left(\mathrm{ONOO}^{-}\right)$and nitrogen dioxide production. Peroxynitrite destroys surfactant by lipid peroxidation and prevents further surfactant production, increasing the possibility of alveolar collapse. ${ }^{8}$

Studies disagree on INO pulmonary inflammatory response: some indicate increased and some decreased inflammatory mediator release. ${ }^{9-11}$ These relate to INO dose, local oxidation-reduction potential, other inflammatory mediators, and oxygen-derived free radicals. ${ }^{12}$ Also no study could be found using total antioxidant performance (TAP) assay to compare the effect of protective CMV, with and without INO on lung oxidative stress. The TAP assay, which determines overall antioxidant/oxidative stress, can capture the biological antioxidant network between watersoluble and fat-soluble antioxidants and their interactions

\section{QUICK LOOK}

\section{Current knowledge}

Inhaled nitric oxide improves oxygenation by improving ventilation/perfusion matching, but does not impact mortality in patients with acute respiratory distress syndrome.

\section{What this paper contributes to our knowledge}

In an animal model of acute lung injury, delivery of inhaled nitric oxide attenuates oxidative stress and reduces lung inflammation.

against oxidative stress. ${ }^{13}$ This method has been validated by Beretta et al ${ }^{14}$ and can be applied to tissues. ${ }^{15}$ It is based on a lipophilic radical generator 2,2'-azobis(4-methoxy2,4-dimethylvaleronitrile) (MeO-AMVN) and a lipophilic oxidizable substrate (4,4-difluoro-5-(4-phenyl-1,3-butadienyl)-4-bora-3a,4a-diaza-s-indacene-3-undecanoic acid [BODIPY]) that specifically measures the lipid compartment oxidizability related to fat-soluble and water-soluble antioxidants acting through a synergistic/cooperative mechanism. ${ }^{14}$

Our hypothesis is that early introduction of low dose INO is protective in a model of ALI via surfactant depletion. The objective of this study was to analyze the early effects of low INO dose on oxygenation, oxidative stress, and inflammatory and histopathological lung injury in a rabbit model of ALI under protective mechanical ventilation.

\section{Methods}

\section{Design, Animals, and Instrumentation}

This was a prospective, sham controlled, in vivo animal study. Rabbits were cared for in accordance with United States National Institutes of Health guidelines and BC Directive 86/609/EEC. This study was approved by the Experimental Research and Ethics Committee of Botucatu Medical School, Sao Paulo State University (protocol number 600).

Forty $2.0-3.0 \mathrm{~kg}$ Norfolk white rabbits were anesthetized intramuscularly with ketamine $(50 \mathrm{mg} / \mathrm{kg})$ and xylazine $(2 \mathrm{mg} / \mathrm{kg})$. The animals were preoxygenated during spontaneous breathing with $100 \%$ oxygen by nose catheter. A tracheotomy was performed by inserting a 3.0$3.5 \mathrm{~mm}$ inner-diameter tracheal tube (Portex, Hythe, United Kingdom) and securing it with umbilical tape. Ventilation was then initiated using a Galileo Gold ventilator (Hamilton Medical, Bonaduz, Switzerland) in adaptive pressure ventilation (also known as volume targeted pressure con- 
trol) mode with the following initial parameters: $\mathrm{F}_{\mathrm{IO}_{2}}=$ 1.0 , tidal volume $\left(\mathrm{V}_{\mathrm{T}}\right)=6 \mathrm{~mL} / \mathrm{kg}, \mathrm{PEEP}=5 \mathrm{~cm} \mathrm{H}_{2} \mathrm{O}$, respiratory rate $=40$ breaths $/ \mathrm{min}$, inspiratory time $=$ 0.5 second. These settings were maintained for $15 \mathrm{~min}$ to achieve stabilization. After tracheotomy had been performed, a vascular catheter was inserted into the common carotid artery (22 gauge Jelco, Introcan Safety-B-Braun, Melsungen, Germany), and a double lumen catheter (5 French, Arrow International, Reading, Philadelphia, Pennsylvania) was advanced into the superior vena cava through the jugular vein. The arterial catheter was used to measure blood gases and arterial blood pressures, using a LogiCal monitoring system (Medex, Dublin, Ohio) connected to a conventional physiological monitor (2010, Dixtal, Manaus, Brazil). The double lumen catheter was used for sedative, maintenance fluid, and vasoactive drug infusion. Anesthesia was maintained with $10 \mathrm{mg} / \mathrm{kg} / \mathrm{h}$ intravenous ketamine. Muscle paralysis was induced by $0.2 \mathrm{mg} / \mathrm{kg}$ intravenous pancuronium bromide and maintained with $0.1 \mathrm{mg} / \mathrm{kg}$ doses as needed. If mean arterial pressure fell below $50 \mathrm{~mm} \mathrm{Hg}$ during the experiment, $0.5-1 \mu \mathrm{g} / \mathrm{kg} / \mathrm{min}$ intravenous noradrenaline was initiated. The need for vasoactive support was recorded by using a vasoactive-inotropic score. ${ }^{16}$ Maintenance fluid was delivered by continuous infusion of $0.9 \%$ saline containing $5 \%$ dextrose at $4 \mathrm{~mL} / \mathrm{kg} / \mathrm{h}$. Core temperature was continuously monitored by esophageal probe and body temperature maintained at $38-39^{\circ} \mathrm{C}$ with electric warming pads. Continuous pulse oximetry was performed with the probe placed on a shaved portion of the rabbit's thigh.

\section{Lung Injury Induction}

Lung injury was induced by lung lavage, using $30 \mathrm{~mL} / \mathrm{kg}$ aliquots of $0.9 \%$ warm $\left(38^{\circ} \mathrm{C}\right)$ saline solution. ${ }^{17,18}$ Briefly, after disconnecting the animal from the ventilator, the saline was introduced by gravity through a side port of the tracheal tube at a maximum pressure of $30 \mathrm{~cm} \mathrm{H}_{2} \mathrm{O}$. The animals were gently rocked from side to side for a few seconds and the saline passively drained from the tracheal tube, and then suction was applied with an endotracheal suction catheter. This procedure was repeated 6 times, with 2 minute intervals between each lavage, during which time the animals were ventilated. After stabilization, arterial blood gas was sampled to verify that the animals were hypoxemic ( 2 values of $\mathrm{P}_{\mathrm{aO}_{2}} \leq 200 \mathrm{~mm} \mathrm{Hg}, 15 \mathrm{~min}$ apart). If lung injury was not confirmed, lung lavage was restarted and $\mathrm{P}_{\mathrm{aO}_{2}} / \mathrm{F}_{\mathrm{IO}_{2}}$ reassessed after every 2 washes. After stabilization, the animals were given two 30-second sustained inflations with a mean airway pressure of $30 \mathrm{~cm} \mathrm{H}_{2} \mathrm{O}$, to promote lung recruitment and equalize volume history. ${ }^{17}$

\section{Inhaled Nitric Oxide Administration}

INO was administered at $5 \mathrm{ppm}$, according to previously described guidelines and techniques ${ }^{7}$ throughout the 4-hour protocol, which began soon after lung injury was confirmed. Briefly, NO blended with nitrogen was obtained from 20-L tanks connected to a pressure regulator (White Martins Gases Industriais-Praxair, Rio de Janeiro, Brazil). Tank concentration was certified by the suppliers as 300 ppm nitric oxide in nitrogen. NO was continuously delivered to the animals via flow meter, directly into the inspiratory limb of the ventilator circuit, distal to the humidifier, from a point $30 \mathrm{~cm}$ distal to the animal's tracheal tube. INO and nitrogen dioxide $\left(\mathrm{NO}_{2}\right)$ concentrations were measured using an $\mathrm{NO} / \mathrm{NO}_{2}$ electrochemical sensor (JP Moryia, São Paulo, Brazil) from samples of circuit gas obtained as close as possible to the tracheal tube via a Y-piece. The gas sensor was calibrated before use every day. Audiovisual alarms were calibrated at $1 \mathrm{ppm}$ above administered INO dose and at a maximum of $3 \mathrm{ppm}$ $\mathrm{NO}_{2}$ concentration. The delivery system was flushed thoroughly before use.

\section{Experimental Groups}

Animals were assigned to one of 4 groups: sham control (control group, no. $=10, \mathrm{~V}_{\mathrm{T}}=6 \mathrm{~mL} / \mathrm{kg}$, PEEP $=5 \mathrm{~cm} \mathrm{H}_{2} \mathrm{O}$ ), ALI+ventilation (no-INO group, no. $=10, \mathrm{~V}_{\mathrm{T}}=6 \mathrm{~mL} / \mathrm{kg}$, PEEP $=10 \mathrm{~cm} \mathrm{H} \mathrm{H}_{2} \mathrm{O}$, plateau pressure limited to $\left.\leq 30 \mathrm{~cm} \mathrm{H}_{2} \mathrm{O}\right), \mathrm{ALI}+$ ventilation + INO (INO group, no. $=10, \mathrm{~V}_{\mathrm{T}}=6 \mathrm{~mL} / \mathrm{kg}, \mathrm{PEEP}=10 \mathrm{~cm}$ $\mathrm{H}_{2} \mathrm{O}$, plateau pressure limited to $\leq 30 \mathrm{~cm} \mathrm{H}_{2} \mathrm{O}$, and INO $5 \mathrm{ppm}$ ), and healthy group (no. $=10$, animals studied for oxidative stress analysis without ALI and mechanical ventilation).

The animals were ventilated using a Galileo Gold ventilator (Hamilton Medical, Bonaduz, Switzerland) with respiratory rate set at $40-50$ breaths/min to reach the targeted $\mathrm{P}_{\mathrm{aCO}_{2}}(40-45 \mathrm{~mm} \mathrm{Hg})$, and $\mathrm{F}_{\mathrm{IO}_{2}}$ was maintained at 1.0 throughout the experiment. Animals received adjustments in ventilation, as described by others ${ }^{17,18}$ using the same experimental model. Arterial blood gas was obtained before (baseline), after lung injury induction, and every $30 \mathrm{~min}$ until the end of the 4 hours observation period. Samples were analyzed by an ABL-3 blood gas analyzer (Chiron Rapid Lab 865, Bayer).

\section{Tissue Collection}

Tissue was collected as per Rotta et al. ${ }^{17}$ Briefly, at the end of the experiment the animals were sacrificed by rapid ketamine infusion. The tracheal tube was clamped and the thorax was carefully opened to observe for signs of pneumothorax, confirm proper catheter placement, and to har- 
vest tissue for histopathological and bronchoalveolar lavage (BAL) analysis. For BAL analysis (no. $=5$ for each group), the right main bronchus was clamped using surgical tape, the lung and heart removed en bloc from the thoracic cavity, and the left lung submitted to BAL twice, using $15 \mathrm{~mL} / \mathrm{kg}$ of normal saline (no. $=5$ for each group). The drained fluid was collected for analysis. The right lung was dissected and stored for oxidative stress analysis (no. $=10$ for each group). Left lungs not instrumented for BAL were dissected for histopathology (no. $=5$ for each group). Right lung tissue specimens were snap frozen in liquid nitrogen and stored at $-80^{\circ} \mathrm{C}$ until analysis.

\section{Bronchoalveolar Lavage}

BAL fluid was collected and total number of cells counted in a hemocytometer. Differential counting was by morphological examination, using panotic staining and polymorphonuclear (PMN) leukocyte percentages were assessed.

\section{Histopathological Analysis}

Left lungs were collected from all groups and used for histopathological analysis. Tissues were filled with $10 \%$ buffered formalin. Alveolar spaces were filled and alveolar architecture preserved by slow gravity formalin drip at a maximum pressure of $30 \mathrm{~cm} \mathrm{H}_{2} \mathrm{O}$. After at least 48 hours fixation, fragments were embedded in paraffin and axial lung sections made, stained with hematoxylin and eosin, and blind examined by 2 independent pathologists. Ten microscopic fields were randomly selected for examination of each slide, totaling 20 tests for each animal. Pulmonary histological damage was quantified by a scoring system using 7 variables (alveolar and interstitial inflammation, alveolar and interstitial hemorrhage, edema, atelectasis, and necrosis). Injury severity was graded for each of the 7 variables as follows: 0 to 4 point scale: 0 (no injury), 1 ( $0-25 \%$ injury), 2 (26-50\% injury), 3 (51-75\% injury), 4 (76-100\% injury). The maximum possible score was 28 and the lowest zero. ${ }^{19}$

\section{Total Antioxidant Performance Analysis in Lung Tissue}

TAP assay was used to measure oxidative stress status of rabbit lung from all groups. TAP in rabbit lung tissue was quantified by comparing the area under the curve relative to the oxidation kinetics of phosphatidylcholine liposome suspension used as the reference biological matrix. ${ }^{16}$ Control liposomes were prepared as previously validated in animal tissue by Ferreira et al. ${ }^{15}$ The dorsal portion of the right lung was weighed $(0.4 \mathrm{~g})$, minced, and homogenized for 20 seconds on ice with $2 \mathrm{~mL}$ phosphate buffered saline (100 mM, pH 7.4) using an Ultra-Turrax T8 homogenizer (IKA, Wilmington, North Carolina). Ali- quots of supernatant for TAP were collected after centrifuging lung tissue homogenate at $800 \mathrm{~g}$ for $15 \mathrm{~min}$ in an Sorvall RT 6000 refrigerated centrifuge (Du Pont, Newtown, Connecticut). Protein concentration was determined by BCA (bicinchoninic acid) protein assay. ${ }^{14}$

\section{Determination of Plasma Total Nitric Oxide Products}

Combined nitrate/nitrite (NOx) measurement was used to determine total NO concentration in rabbit plasma, ${ }^{20}$ with minor modifications, using a nitrate/nitrite fluorometric assay kit (Cayman Chemical, Ann Arbor, Michigan). The detection limit for this assay was $0.2 \mu \mathrm{M}$.

\section{Statistical Analysis}

Data were analyzed by SigmaStat (version 2.03, SPSS, Chicago, Illinois). Normally distributed data were compared between different treatment groups by one-way analysis of variance with all pairwise comparison procedures (Student-Newman-Keuls test) and expressed as means $\pm \mathrm{SD}$. Data showing non-normal distribution were compared by Kruskal-Wallis one-way analysis of variance on ranks, with all pairwise comparisons by the Dunn test and expressed as median (range). Intragroup comparisons at different time points were performed using Friedman repeated measures analysis of variance on ranks with all pairwise multiple comparison procedures by the Dunnett method. Contingency tables of categorical data were compared by the Fisher exact test. Statistical significance was defined as $P<.05$.

\section{Results}

There were no statistical differences between groups for weight (control group $2.7 \pm 0.24 \mathrm{~kg}$, no-INO group $2.6 \pm 0.25 \mathrm{~kg}$, INO group $2.6 \pm 0.25 \mathrm{~kg}, P=.74)$ and number of lavages to induce lung injury (no-INO group $8.5 \pm 3.7$, INO group $8.3 \pm 2.7, P=.15$ ). Percentages of fluid recovered from lavaged lungs were $84.2 \%$ and $85.1 \%$ for no-INO group and INO group, respectively $(P=.82)$.

One animal from the control group (refractory hypotension), 3 from the no-INO group (pneumothorax and tracheal bleeding), and 2 from the INO group (refractory hypotension and arterial bleeding) died.

\section{Hemodynamics, Lung Mechanics, and Gas Exchange}

The injured groups showed significant hypoxemia, $\left(\mathrm{P}_{\mathrm{aO}}\right.$ : control group $438 \pm 87 \mathrm{~mm} \mathrm{Hg}$, no-INO group $80 \pm 13$ $\mathrm{mm} \mathrm{Hg}$, INO group $81 \pm 24 \mathrm{~mm} \mathrm{Hg}, P<.001$ ), poorer ventilation, decreased pulmonary compliance, and increased airway pressure after lung injury, compared to 
Table 1. Oxygenation Indexes, Pulmonary Mechanics, Metabolic, and Hemodynamic Data

\begin{tabular}{|c|c|c|c|c|}
\hline & \multicolumn{2}{|c|}{$\begin{array}{c}\text { No INO Group } \\
(\text { no. }=10) \\
(\text { mean } \pm \text { SD })\end{array}$} & \multicolumn{2}{|c|}{$\begin{array}{c}\text { INO Group } \\
(\text { no. }=10) \\
(\text { mean } \pm \text { SD })\end{array}$} \\
\hline & Baseline & Lung Injury & Baseline & Lung Injury \\
\hline $\mathrm{P}_{\mathrm{aO}_{2}}(\mathrm{~mm} \mathrm{Hg})$ & $475 \pm 77 *$ & $80 \pm 13 * \dagger$ & $446 \pm 74 *$ & $81 \pm 24 * \dagger$ \\
\hline Oxygenation index $\$\left(\mathrm{~cm} \mathrm{H}_{2} \mathrm{O} / \mathrm{mm} \mathrm{Hg}\right)$ & $1.8 \pm 0.7 *$ & $12 \pm 2.0^{*} \dagger$ & $1.7 \pm 0.4^{*}$ & $14 \pm 5.2 * \dagger$ \\
\hline Pulmonary compliance $\left(\mathrm{mL} / \mathrm{cm} \mathrm{H}_{2} \mathrm{O}\right)$ & $3.3 \pm 0.2 *$ & $1.4 \pm 0.3 * \dagger$ & $3.2 \pm 0.5^{*}$ & $1.3 \pm 0.2 * \dagger$ \\
\hline Mean airway pressure $\left(\mathrm{cm} \mathrm{H}_{2} \mathrm{O}\right)$ & $8.2 \pm 1.8^{*}$ & $10 \pm 1.5^{* \dagger}$ & $7.5 \pm 0.6^{*}$ & $10.3 \pm 0.9 * \dagger$ \\
\hline $\mathrm{P}_{\mathrm{aCO}_{2}}(\mathrm{~mm} \mathrm{Hg})$ & $40 \pm 4.8^{*}$ & $50 \pm 6.0^{* \dagger}$ & $40 \pm 6.0^{*}$ & $47 \pm 6.0 * \dagger$ \\
\hline $\mathrm{pH}$ & $7.1 \pm 0.06^{*}$ & $7.2 \pm 0.06^{* \dagger}$ & $7.3 \pm 0.07^{*}$ & $7.2 \pm 0.05 * \dagger$ \\
\hline Mean arterial pressure $(\mathrm{mm} \mathrm{Hg})$ & $76 \pm 16^{*}$ & $76 \pm 18^{*}$ & $70 \pm 15^{*}$ & $68 \pm 9^{*}$ \\
\hline
\end{tabular}

baseline and the control group. There was also significant metabolic acidosis (Table 1 ).

PEEP was increased in both ALI groups, as per the protocol; there were no statistical differences between groups or moments throughout the experiment $(30 \mathrm{~min}$ : no-INO group $6.7 \pm 0.5 \mathrm{~cm} \mathrm{H}_{2} \mathrm{O}$, INO group $6.6 \pm 0.9 \mathrm{~cm}$ $\mathrm{H}_{2} \mathrm{O} ; 60$ min: no-INO group $8.0 \pm 0.3 \mathrm{~cm} \mathrm{H}_{2} \mathrm{O}$, INO group $8.2 \pm 1.0 \mathrm{~cm} \mathrm{H}_{2} \mathrm{O}: 120$ min: no-INO group $9.5 \pm$ $0.6 \mathrm{~cm} \mathrm{H}_{2} \mathrm{O}$, INO group $9.5 \pm 0.5 \mathrm{~cm} \mathrm{H} \mathrm{H}_{2} \mathrm{O} ; 180 \mathrm{~min}$ : no-INO group $9.8 \pm 0.4 \mathrm{~cm} \mathrm{H}_{2} \mathrm{O}$, INO group $9.7 \pm 0.67$ cm $\mathrm{H}_{2} \mathrm{O}$; 240 min: no-INO group $9.8 \pm 0.4 \mathrm{~cm} \mathrm{H}_{2} \mathrm{O}$, INO group $9.3 \pm 0.8 \mathrm{~cm} \mathrm{H}_{2} \mathrm{O}$ ).

Mean arterial pressure was kept above $50 \mathrm{~mm} \mathrm{Hg}$ with vasoactive support. Both injured groups were greater than control group for vasoactive-inotropic score: control group 0 (range 0-25), no-INO group 50 (range $0-70$ ), INO group 50 (range $0-70)(P=.006)$.

Pulmonary compliance was greater for the control group than for the treated groups. It decreased in ALI groups after lung injury, remaining low throughout the experiment, without a statistical difference between them.

Peak inspiratory pressure and airway pressure increased in the injured groups and were higher than control, showing a deterioration in respiratory mechanics (Fig. 1). Animals that underwent lung lavage displayed worse oxygenation indexes than the control group (Fig. 2). A gradual increase in PEEP improved oxygenation in the no-INO group and the INO group, without any statistical difference between them. However, injured animals did not reach control group values.

\section{Polymorphonuclear Count}

The numbers of recovered PMN cells from BAL fluid were significantly higher in the no-INO group than in the control group and INO group: no-INO group $4.80 \pm 1.64$, control group $0.16 \pm 0.15$, INO group $0.96 \pm 0.35$ PMN cells $\times 10^{6} / \mathrm{BAL}$ fluid/lung $(P<.001)($ Fig. 3$)$.

\section{Histopathology}

Median (range) histopathological injury score was greater for the no-INO group than for the INO group: no-INO group $5(1-16)$, INO group $2(0-5)$, control group $0(0-3)(P<.001)$ (Fig. 4).

\section{Oxidative Injury and Total Nitric Oxide Products}

TAP in lung tissue from the INO group was higher than from the no-INO group, both treated groups being smaller than the healthy group and the control group: healthy group $68 \pm 8.7$, control group $66.4 \pm 6.8$, INO group $56.3 \pm 5.1$, no-INO group $45.9 \pm 3.4$ percent protection/g protein $(P<.001)$, indicating more protection against oxidative stress for the INO group, compared to the no-INO group (Fig. 5). There was no significant difference for NOx concentration between groups: healthy group $5.87 \pm 2.4 \mu \mathrm{M}$, control group 4.54 $\pm 1.1 \mu \mathrm{M}$, no-INO group 4.45 $\pm 2.1 \mu \mathrm{M}$, INO group $5.3 \pm 2.6 \mu \mathrm{M}(P=.07)$.

\section{Discussion}

To our knowledge there is no published study on the effects of INO associated with protective CMV on lung oxidative status determined by TAP assay in pulmonary tissue. Our main findings were that INO attenuated oxidative stress and histopathological and inflammatory lung injury.

Despite possible beneficial effects, many studies have given no clinical value to INO, due to its lack of impact on mortality rate in non-neonatal patients, ${ }^{21,22}$ so that its use has been limited to short-term adjunct therapy in cardio- 
A
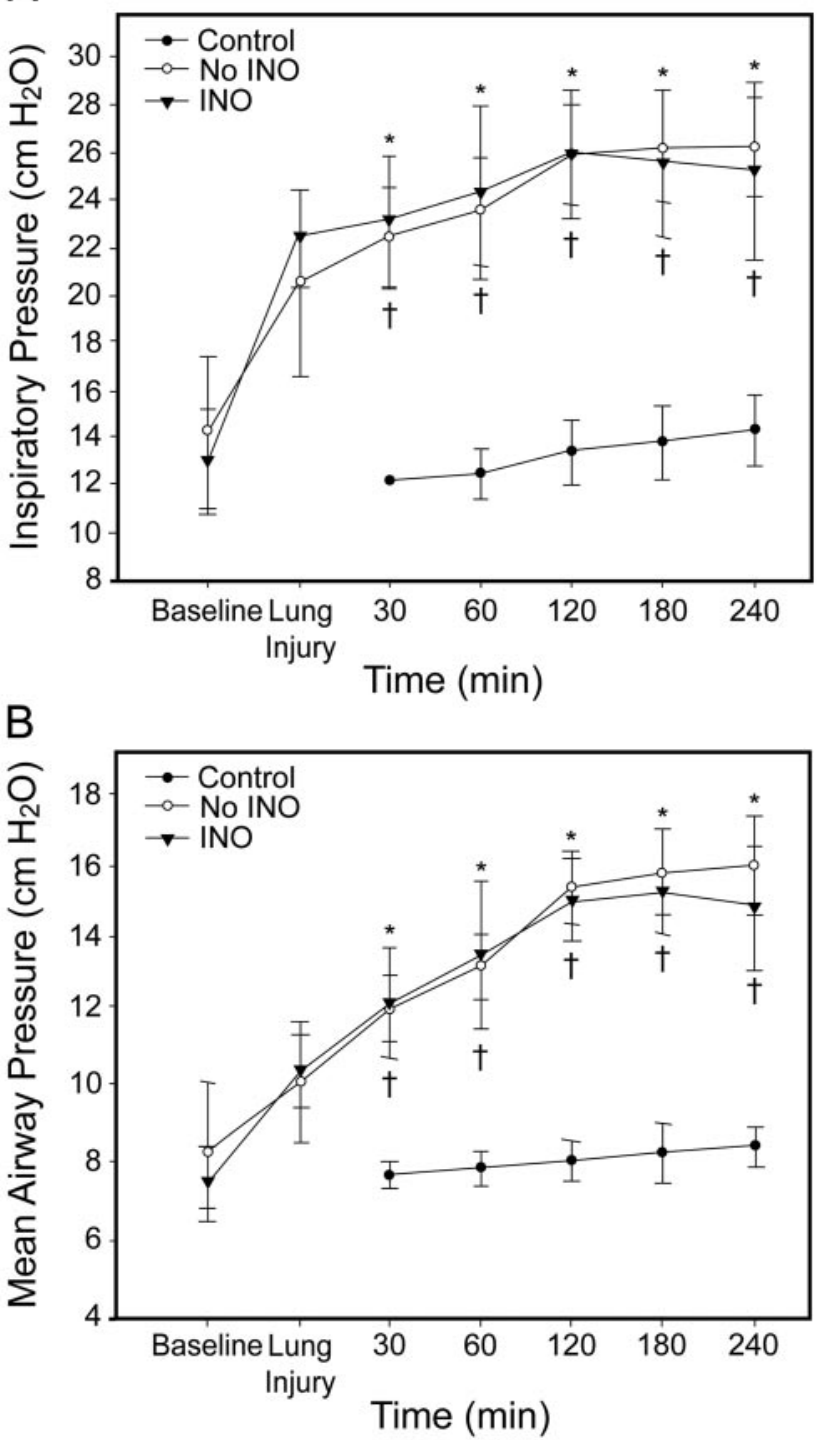

Fig. 1. Peak inspiratory pressure (panel $A)$ and mean airway pressure (panel B) over time for sham control (control group), lung injury without inhaled nitric oxide group (no-INO group), and lung injury plus INO group (INO group). ${ }^{*} P<.001$ comparing no-INO group and control group. $\dagger P<.001$ comparing INO group and control group, by analysis of variance (ANOVA).

respiratory support for patients with acute hypoxemia or life threatening pulmonary hypertension..$^{23}$ Confirming these reports, a recent multiple study meta-analysis showed that INO improved oxygenation without modifying overall clinical outcomes in children and adults with ALI/ARDS. ${ }^{24}$ However, Razavi et al, ${ }^{25}$ assessing the effects of INO on pulmonary inflammation in a mouse model of sepsisinduced ALI, demonstrated that early INO exposure was associated with reduced pulmonary leukocyte infiltration and less oxidative injury. These authors concluded that early INO administration is of clinical benefit in the nat-
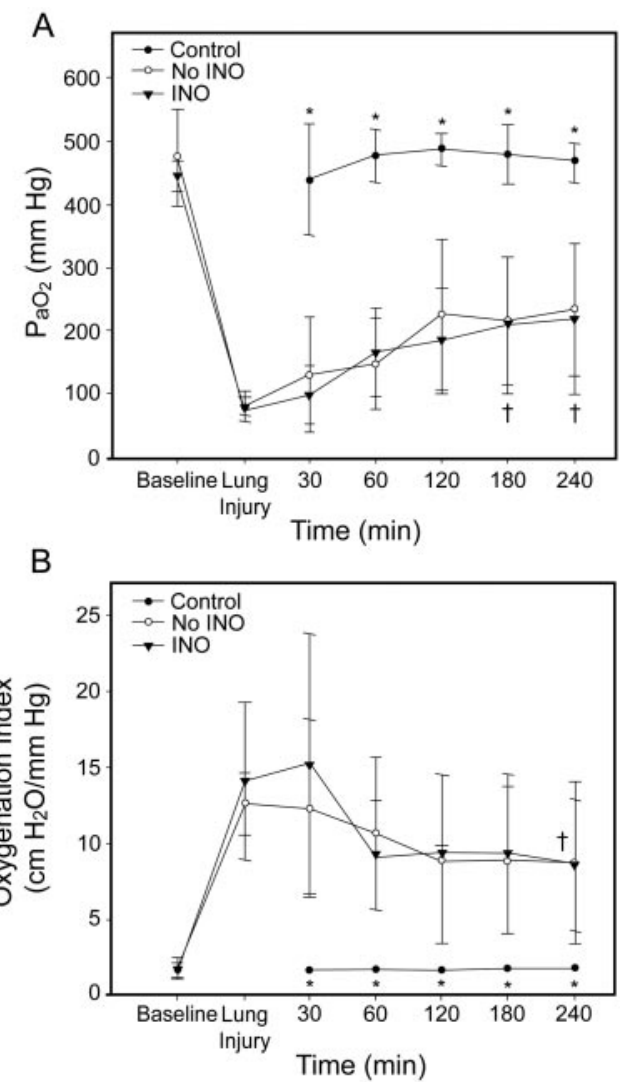

Fig. 2. $\mathrm{P}_{\mathrm{aO}_{2}}$ (panel $A$ ) and oxygenation index (panel B) Oxygenation index $=$ mean airway pressure $\times \mathrm{F}_{\mathrm{IO}_{2}} \times 100 / \mathrm{P}_{\mathrm{aO}_{2}}, \mathrm{~cm} \mathrm{H}_{2} \mathrm{O} / \mathrm{mm} \mathrm{Hg}$ ) over time for sham control (control group), lung injury without inhaled nitric oxide group (no-INO group), and lung injury plus inhaled nitric oxide group (INO group). $\mathrm{P}_{\mathrm{aO}_{2}}$ : ${ }^{*} P<.001$ comparing control group with no-INO group and INO group (analysis of variance [ANOVA], Bonferroni), $† P<.001$ comparing no-INO group and INO group at 180 and 240 min with 30 min repeated measure ANOVA. Oxygenation index: ${ }^{*} P<.001$ comparing control group with no-INO group and INO group (ANOVA, Bonferroni). $† P<.001$ comparing 240 with $30 \mathrm{~min}$ for INO group (repeated measure ANOVA).

ural history of ALI in clinical settings. Moreover, it seems that INO response is better in patients with more severe respiratory failure ${ }^{21}$ and when it is administered soon after ARDS diagnosis. ${ }^{7}$ These results point to early low-dose INO as a way to attenuate lung inflammation. The protective role of INO was also reported by Koh et al, ${ }^{26}$ studying rabbits with ALI induced by lipopolysaccharide infusion.

According to recent recommendations, the clinical use of INO therapy in ARDS must be limited to patients who are optimally ventilated with appropriate PEEP levels, as this seems to recruit additional alveoli for gas exchange. ${ }^{27}$ INO improved oxygenation, demonstrating a positive response in association with protective ventilation. However, $\mathrm{P}_{\mathrm{aO}_{2}}$ in injured groups did not reach control group levels. Interestingly, there was no difference in oxygen- 


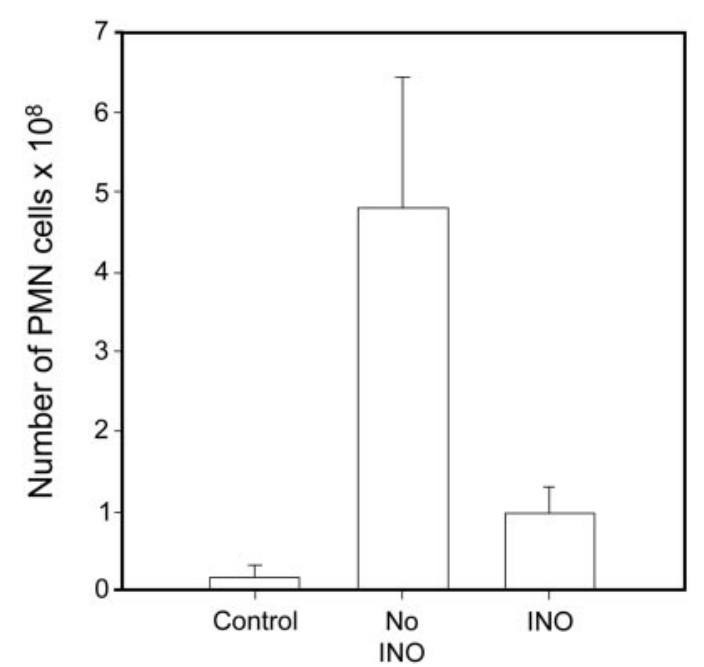

Fig. 3. Number of polymorphonuclear (PMN) leukocyte cells recovered from bronchoalveolar lavage fluid at the end of experiment for sham control (control group), conventional mechanical ventilation without inhaled nitric oxide (no-INO group), and conventional mechanical ventilation with inhaled nitric oxide (INO group): no-INO group $4.80 \pm 1.64>$ control group $0.16 \pm 0.15=$ INO group $0.96 \pm 0.35$. $P<.001$ for both control vs no-INO and no-INO vs INO. The difference between the control group and the INO group is not significant.

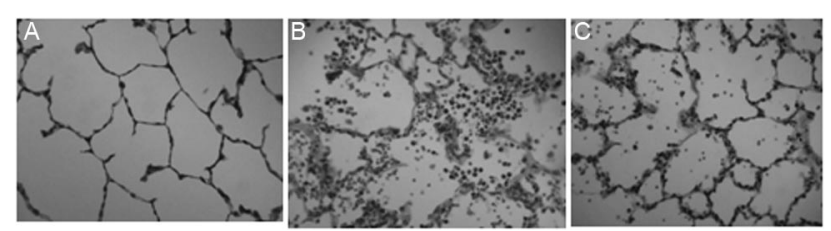

Fig. 4. Optical microscopy digital photomicrographs $(200 \times$, hematoxylin and eosin) of representative samples of lung dependent areas from sham control (control group), conventional mechanical ventilation without inhaled nitric oxide (no-INO group), and conventional mechanical ventilation with inhaled nitric oxide (INO group). Median (range) histopathological injury score: no-INO group $5(1-16)>$ INO group $2(0-5)>$ control group $0(0-3)(P<$ $.001)$.

ation indexes between the no-INO group and the INO group over the 4-hour experimental period, meaning that INO did not influence oxygenation, despite having positive inflammatory and antioxidant effects. This can be explained by many factors. First, there have been reports of responder and non-responder INO models. ${ }^{28}$ Gust et al ${ }^{28}$ observed that, when low doses of endotoxin were added to ARDS induced with oleic acid, animals responded to INO. Second, cytokines, endotoxins, and hypoxia can stimulate NO synthase blocking the hypoxic vasoconstrictor reflex with decreased gas effects. ${ }^{29}$ Finally, as has already been demonstrated, ${ }^{7}$ the effect of INO on oxygenation takes 4 hours to reach its maximum, making it difficult to demonstrate the oxygenation effects of the gas in animal models with limited viability, such as rabbits.

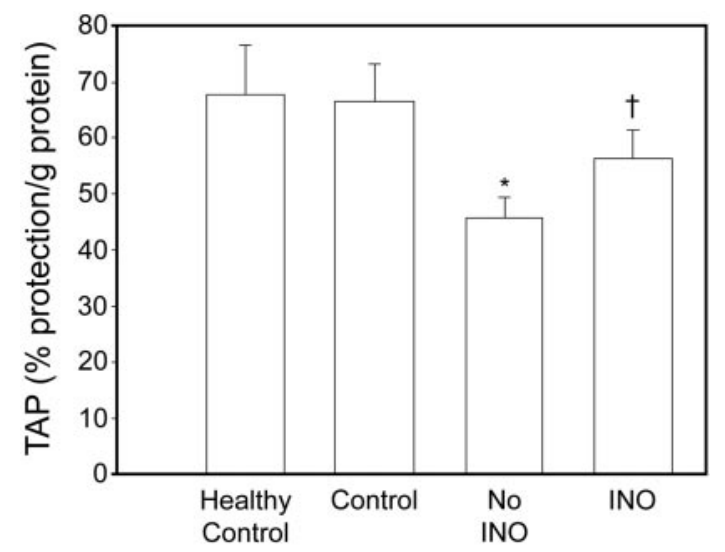

Fig. 5. Lung protection by total antioxidant performance (TAP) assay for healthy control group, sham control (control group), conventional mechanical ventilation without inhaled nitric oxide group (no-INO group), and conventional mechanical ventilation with inhaled nitric oxide group (INO group). ${ }^{*} P<.001$ comparing no-INO group with INO group, healthy group, and control group. $\uparrow P<.001$ comparing INO group with healthy group and control group.

The warm saline lavage model causes inflammatory reaction, with increased vascular permeability and PMN cell activation in bronchoalveolar fluid. ${ }^{30} \mathrm{INO}$, however, can modify cytokine release as well as other inflammatory pathway elements. ${ }^{10}$ Also, the gas has inhibitory effects on the activation of adhesion molecules and oxidative injury, which reflect the number of neutrophils at the pulmonary injury site. ${ }^{31} \mathrm{We}$ observed a significant decrease in PMN cell numbers in animals from the INO group, compared with the no-INO group, indicating that the gas influenced PMN cell migration, probably by inhibiting adhesion molecule expression in these cells and their ligands at the endothelium. ${ }^{17}$ Furthermore, we were able to demonstrate an INO protection effect, as histopathological injury score for the INO group was lower than for the no-INO group. There are no studies describing this result.

While many studies have evaluated the effects of protective ventilation on oxygenation, lung inflammation, and histological injury in animal ALI models, only a few have analyzed oxidative stress. ${ }^{17,18}$

The involvement of oxidant-mediated tissue injury is likely to be an important event in ARDS pathogenesis. ${ }^{32}$ ARDS patients reportedly have low plasma antioxidant concentrations. ${ }^{33}$ Activated leukocyte aggregates in pulmonary microvasculature release reactive oxygen species, which can attack membrane polyunsaturated fatty acid (PUFA), thus initiating a peroxidation process. Peroxidation leads to the loss of cell membrane functional integrity, culminating in an acute increase in alveolar-capillary permeability. In ALI, activated lymphocytes stimulate tumor necrosis factor (TNF) and other cytokines. These lymphokines augment free radical generation by PMN leukocytes, 
macrophages, and other cells, which may ultimately produce ARDS. ${ }^{34}$

Rotta et $\mathrm{al}^{17}$ in a similar ALI rabbit model, studied oxidative stress by measuring malondialdehyde, a nonspecific biomarker of lipid peroxidation. ${ }^{35}$ This assay has been criticized due to its low specificity and sensitivity. ${ }^{36}$ Another marker of oxidative stress (myeloperoxidase) in a rabbit model of gastric juice aspiration showed reduced lung oxidative damage in high-frequency oscillatory ventilation. ${ }^{37}$ Even though myeloperoxidase has reportedly been associated with tissue damage involving inflammatory cells, it only implicates oxidant activity of neutrophils and other myeloperoxidase-containing cells. ${ }^{38}$

We demonstrated that protective ventilation plus INO is associated with improved total antioxidant capacity assessed by TAP. Many factors could have influenced this finding. It has been shown that INO does not decrease inflammatory response when inflammation is already in progress; however, its early use may attenuate it. Also, low INO doses seem to be beneficial, while higher doses may contribute to inflammatory injury. ${ }^{39}$ It is therefore possible that the early application of low dose INO (5 ppm) may have attenuated oxidative lung injury in our model.

Our study has some potential limitations. First, no single animal model can reproduce all the characteristics of ALI/ARDS in humans. For instance, ALI rabbit models produce twice the amount of nitric oxide as human ARDS. ${ }^{30}$ However, one of the most commonly used ALI animal models is alveolar lavage with warmed normal saline; this is primarily a surfactant depletion model, which causes lung injury very similar to that in human ARDS, in respect to its effects on oxygenation, pulmonary compliance and atelectasis, and perivascular/peribronchial edema. However, it does induce less macrophage and neutrophil infiltration unless another injury, such as mechanical ventilation, is added. ${ }^{30}$ Additionally, surfactant removal can interfere with lung inflammatory/immune response and oxidative metabolism because surfactant inhibits neutrophil respiratory activation and has an antioxidant effect on alveolar macrophages. ${ }^{40}$ Second, we did not permit changes in ventilatory settings (for instance raising PEEP levels above $10 \mathrm{~cm} \mathrm{H}_{2} \mathrm{O}$ ), which may have contributed to sustained hypoxia. One of the main factors affecting response to the gas is alveolar recruitment level. The lungs may have been very atelectasic and therefore not adequately recruited to demonstrate a difference between the with and without INO groups. However, we believe modifications in ventilatory parameters may introduce a bias, with other confusing variables.

\section{Conclusions}

In conclusion, early use of low dose INO attenuates oxidative stress and histopathological and inflammatory lung injury in a saline-lavaged rabbit model of ALI. These findings strengthen the hypothesis that INO should be used early in the disease course; however, this needs better clarification in clinical trials.

\section{ACKNOWLEDGMENTS}

We thank the entire team in the Experimental Research Laboratory for their expert assistance, and Colin E Knaggs for text revision.

\section{REFERENCES}

1. de Hemptinne Q, Remmelink M, Brimioulle S, Salmon I, Vincent JL. ARDS: a clinicopathological confrontation. Chest 2009;135(4): 944-949.

2. Lamb NJ, Gutteridge JM, Baker C, Evans TW, Quinlan GJ. Oxidative damage to proteins of bronchoalveolar lavage fluid in patients with acute respiratory distress syndrome: evidence for neutrophilmediated hydroxylation, nitration, and chlorination. Crit Care Med 1999;27(9):1738-1744.

3. The Acute Respiratory Distress Syndrome Network. Ventilation with lower tidal volumes as compared with traditional tidal volumes for acute lung injury and the acute respiratory distress syndrome. N Engl J Med 2000;342(18):1301-1308.

4. Ranieri VM, Suter PM, Tortorella C, De Tullio R, Dayer JM, Brienza A, et al. Effect of mechanical ventilation on inflammatory mediators in patients with acute respiratory distress syndrome: a randomized controlled trial. JAMA 1999;282(1):54-61.

5. Slutsky AS. Lung injury caused by mechanical ventilation. Chest 1999;116(1 Suppl):9S-15S.

6. Randolph AG. Management of acute lung injury and acute respiratory distress syndrome in children. Crit Care Med 2009;37(8):1-7.

7. Fioretto JR, de Moraes MA, Bonatto RC, Ricchetti SM, Carpi MF. Acute and sustained effects of early administration of inhaled nitric oxide to children with acute respiratory distress syndrome. Pediatr Crit Care Med 2004;5(5):469-474.

8. Haddad IY, Zhu S, Crow J, Barefield E, Gadilhe T, Matalon S. Inhibition of alveolar type II cell ATP and surfactant synthesis by nitric oxide. Am J Physiol 1996;270(6 Pt 1):L898-L906.

9. Bloomfield GL, Holloway S, Ridings PC, et al. Pretreatment with inhaled nitric oxide inhibits neutrophil migration and oxidative activity resulting in attenuated sepsis-induced acute lung injury. Crit Care Med 1997;25(4):584-593.

10. Chollet-Martin S, Gatecel C, Kermarrec N, Gougerot-Pocidalo MA, Payen DM. Alveolar neutrophil functions and cytokine levels in patients with the adult respiratory distress syndrome during nitric oxide inhalation. Am J Respir Crit Care Med 1996;153(3):985-990.

11. Sittipunt C, Steinberg KP, Ruzinski JT, Myles C, Zhu S, Goodman $\mathrm{RB}$, et al. Nitric oxide and nitrotyrosine in the lungs of patients with acute respiratory distress syndrome. Am J Respir Crit Care Med 2001;163(2):503-510.

12. Laroux FS, Pavlick KP, Hines IN, Kawachi S, Harada H, Bharwani $\mathrm{S}$, et al. Role of nitric oxide in inflammation. Acta Physiol Scand 2001;173(1):113-118.

13. Yeum KJ, Beretta G, Krinsky NI, Russell RM, Aldini G. Synergistic interactions of antioxidant nutrients in a biological model system. Nutrition 2009;25(7-8):839-846.

14. Beretta G, Aldini G, Facino RM, Russell RM, Krinsky NI, Yeum KJ. Total antioxidant performance: a validated fluorescence assay for the measurement of plasma oxidizability. Anal Biochem 2006;354(2): 290-298.

15. Ferreira AL, Yeum KJ, Matsubara LS, Matsubara BB, Correa CR, Pereira EJ, et al. Doxorubicin as an antioxidant: maintenance of 
myocardial levels of lycopene under doxorubicin treatment. Free Radic Biol Med 2007;143(5):740-751.

16. Gaies MG, Gurney JG, Yen AH, Napoli ML, Gajarski RJ, Ohye RG, et al. Vasoactive-inotropic score as a predictor of morbidity and mortality in infants after cardiopulmonary bypass. Pediatr Crit Care Med 2010;11(2):234-238.

17. Rotta AT, Gunnarsson B, Fuhrman BP, Hernan LJ, Steinhorn DM. Comparison of lung protective ventilation strategies in a rabbit model of acute lung injury. Crit Care Med 2001;29(11):2176-2184.

18. Imai Y, Nakagawa S, Ito Y, Kawano T, Slutsky AS, Miyasaka K. Comparison of lung protection strategies using conventional and high-frequency oscillatory ventilation. J Appl Physiol 2001;91(4): 1836-1844.

19. Mrozek KM, Smith DR, Bing PA, Meyers PA, Simonton SC, Connett JE, Mammel MC. Exogenous surfactant and partial liquid ventilation: physiologic and pathologic effects. Am J Respir Crit Care Med 1997;156(4 Pt 1):1058-1065.

20. Miles AM, Wink DA, Cook JC, Grisham MB. Determination of nitric oxide using fluorescence spectroscopy. Methods Enzymol 1996; 268:105-120.

21. Dobyns EL, Cornfield DN, Anas NG, Fortenberry JD, Tasker RC, Lynch A, et al. Multicenter randomized controlled trial of the effects of inhaled nitric oxide therapy on gas exchange in children with acute hypoxemic respiratory failure. J Pediatr 1999;134(4): 406-412.

22. Ream RS, Hauver JF, Lynch RE, Kountzman B, Gale GB, Mink RB. Low dose inhaled nitric oxide improves the oxygenation and ventilation of infants and children with acute, hypoxemic respiratory failure. Crit Care Med 1999;27(5):989-996.

23. Griffiths MJD, Evan TW. Inhaled nitric oxide therapy in adults. N Engl J Med 2005;353(25):2683-2695.

24. Adhikari NK, Burns KE, Friedrich JO, Granton JT, Cook DJ, Meade MO. Effect of nitric oxide on oxygenation and mortality in acute lung injury: systematic review and meta-analysis. BMJ 2007; 334(7597):757-758

25. Razavi HM, Werhun R, Scott JA, et al. Effects of inhaled nitric oxide in a mouse model of sepsis-induced acute lung injury. Crit Care Med 2002;30(4):868-873.

26. Koh Y, Kang JL, Park W, Pack IS, Lee HS, Kim J, et al. Inhaled nitric oxide down-regulates intrapulmonary nitric oxide production in lipopolysaccharide-induced acute lung injury. Crit Care Med 2001; 29(6):1169-1174.
27. Fioretto JR, Carpi MF, and Bonatto RC. Inhaled nitric oxide for children with acute respiratory distress syndrome. In Esquinas A, Volsko TA, editors. Yearbook of respiratory care clinics and applied technologies. Murcia: Tipografia San Francisco S.A.;2008:747-751.

28. Gust R, McCarthy TJ, Kozlowski J, Stephenson AH, Schuster DP. Response to inhaled nitric oxide in acute lung injury depends on distribution of pulmonary blood flow prior to its administration. Am J Respir Crit Care Med 1999;159(2):563-570.

29. Weimann J, Bloch KD, Takata M, Steudel W, Zapol WM. Congenital NOS2 deficiency protects mice from LPS-induced hyporesponsiveness to inhaled nitric oxide. Anesthesiology 1999;91(6):17441753.

30. Matute-Bello G, Frevert CW, and Martin TR. Animal models of acute lung injury. Am J Physiol Lung Cell Mol Physiol 2008;295(3): L379-L399.

31. Kubes P, Suzuki M, Granger DN. Nitric oxide: an endogenous modulator of leukocyte adhesion. Proc Natl Acad Sci USA 1991;88(11): 4651-4655.

32. Grune T, Berger MM. Markers of oxidative stress in ICU clinical settings: present and future. Curr Opin Clin Nutr Metab Care 2007; 10(6):712-717.

33. Quinlan GJ, Evans TW, Gutteridge JM. Oxidative damage to plasma proteins in adult respiratory distress syndrome. Free Radic Res 1994; 20(5):289-298

34. Kumar KV, Rao SM, Gayani R, Mohan IK, Naidu MU. Oxidant stress and essential fatty acids in patients with risk and established ARDS. Clin Chim Acta 2000;298(1-2):111-120.

35. Vahlquist A, Duvic M. Retinoids and carotenoids in dermatology. JAMA 2008;99:1611-1612.

36. Grotto D, Maria LS, Valentine J, et al. Importance of the lipid peroxidation biomarkers and methodological aspects for malondialdehyde quantification. Quim Nova 2009;32:169-174.

37. Allardet-Servent J, Bregeon F, Delpierre S, Steinberg JG, Payan MJ, Ravailhe S, Papazian L. High-frequency percussive ventilation attenuates lung injury in a rabbit model of gastric juice aspiration. Intensive Care Med 2008;34(1):91-100.

38. Winterbourn CC, Kettle AJ. Biomarkers of myeloperoxidase-derived hypochlorous acid. Free Radic Biol Med 2000;29(5):403-409.

39. Wang T, Kebir DE, Blaise G. Inhaled nitric oxide in 2003: a review of its mechanisms of action. Can J Anesth 2003;50(8):839-846.

40. Mallory G. Surfactant proteins: role in lung physiology and disease in early life. Paediatr Respir Rev 2001;2(2):151-158. 